\title{
$\mathrm{pH}$ 감응성 $\mathrm{P}(\mathrm{MAA}-\mathrm{co}-\mathrm{PEGMA})$ 수화젤이 알부민의 방출과 안정성에 미치는 영향
}

\author{
양주승 · 김범상 \\ 홍익대학교 화학공학과 \\ (2012년 8월 7일 접수, 2012년 12월 5일 수정, 2012년 12월 24일 채택)
}

\section{Effect of pH-Sensitive P(MAA-co-PEGMA) Hydrogels on Release and Stability of Albumin}

\author{
Juseung Yang and Bumsang Kim \\ Department of Chemical Engineering, Hongik University, 94 Wausan-ro, Mapo-gu, Seoul 121-791, Korea \\ (Received August 7, 2012; Revised December 5, 2012; Accepted December 24, 2012)
}

\begin{abstract}
초록: 본 연구에서는 $\mathrm{pH}$ 감응성 수화젤 입자를 이용하여 외부환경에 불안정한 활성물질을 화장품 제형 내에서는 안정하게 보존하고, 피부에 도포 시 빠른 방출로 피부에 흡수될 수 있는 지능형 전달시스템의 구현 가능성을 확인 하기 위하여, 분산광중합을 이용하여 $\mathrm{pH}$ 감응성을 가지는 P(MAA-co-PEGMA) 수화젤 입자를 평균 크기 약 $2 \mu \mathrm{m}$ 의 구형 입자로 합성하였다. 합성된 P(MAA-co-PEGMA) 수화젤 입자는 수화젤의 MAA에 존재하는 카르복시기의 이온화에 의하여 $\mathrm{pH} 5$ 를 전후로 한 급격한 팽윤비의 변화를 보여주었다. $\mathrm{pH}$ 에 따른 수화젤 내부에 탑재된 알부민 의 방출 및 피부투과 실험결과, $\mathrm{P}(\mathrm{MAA}-c o-\mathrm{PEGMA})$ 수화젤 입자는 $\mathrm{pH}$ 4.0에서는 소량의 알부민이 방출되어 피부 투과가 거의 일어나지 않은 반면, $\mathrm{pH}$ 6.0에서는 초기부터 다량의 알부민이 방출되어 상대적으로 높은 피부투과율을 나타내었다. 펩신을 이용한 알부민의 안정성 실험결과, P(MAA-co-PEGMA) 수화젤은 내부에 탑재된 알부민을 외부 환경으로부터 보호하여 알부민의 안정성을 유지시켜 주었다.
\end{abstract}

\begin{abstract}
H}$-sensitive P(MAA-co-PEGMA) hydrogel particles were prepared and their feasibility as smart delivery carriers for cosmetic ingredients was evaluated. P(MAA-co-PEGMA) hydrogel particles having an average size of approx. $2 \mu \mathrm{m}$ were synthesized via dispersion photopolymerization. There was a drastic change in the swelling ratio of P(MAAco-PEGMA) particles at a $\mathrm{pH}$ of around 5 due to the ionization of MAA in the hydrogel and as the amount of MAA in the hydrogel increased, the swelling ratio increased at a $\mathrm{pH}$ above 5. The P(MAA-co-PEGMA) hydrogel particles showed a pH-sensitive release behavior. Thus, at $\mathrm{pH} 4$ almost none of the albumin permeated through the skin while at $\mathrm{pH} 6$ relatively high skin permeability was obtained. The albumin loaded in the P(MAA-co-PEGMA) hydrogel particles was hardly degraded in the presence of pepsin and its stability was maintained.
\end{abstract}

Keywords: pH-sensitive, hydrogel particles, albumin stability, smart delivery system, skin permeability.

\section{서 론}

친수성 가교 고분자인 고분자 수화젤(hydrogel)은 수용액에 서 화학적 또는 물리적 가교에 의하여 용해되지 않고 다량의 물을 내부에 함유하여 팽윤할 수 있는 3차원 그물 구조를 갖 고 있다. 그리고 다량의 물을 함유한 상태의 수화젤은 생체 의 조직(tissue)과 유사한 거동을 보이므로 인체에 적용 시, 주 변의 세포 또는 조직에 미치는 영향을 최소화하여 우수한 생 체적합성을 나타낼 수 있다..$^{-5}$ 수화젤 중, 특정한 수화젤은 고 분자 사슬에 포함하고 있는 기능성 그룹의 종류에 따라서 $\mathrm{pH}$,

To whom correspondence should be addressed.

E-mail: bskim@hongik.ac.kr
온도, 전자기장, 이온 강도 및 용매 조성 등의 외부자극에 감 응하여 가역적 혹은 비가역적으로 수화젤 네트워크의 구조적 변화를 일으킬 수 있는데, 이러한 수화젤을 자극 감응형 수 화젤이라고 한다. 자극 감응형 수화젤은 우수한 생체적합성 과 외부환경에 대한 감응성 등의 특징 때문에 오래 전부터 지능형 약물 전달시스템 분야에서 활발하게 연구되어 오고 있다. ${ }^{6-10}$ 자극 감응형 수화젤 중 $\mathrm{pH}$ 감응성 수화젤은 주변의 $\mathrm{pH}$ 변화에 따라서 수화젤 네트워크의 구조적 변화를 일으켜 선택적으로 약물의 방출을 조절할 수 있는데, $\mathrm{pH}$ 감응성 수 화젤 중 일부 수화젤은 자신의 $\mathrm{pK}_{\mathrm{a}}$ 보다 낮은 $\mathrm{pH}$ 에서는 수화 젤 네트워크가 팽윤되지 않기 때문에 내부에 탑재된 물질의 방출을 막아서 주변으로부터 탑재된 물질을 보호하는 반면, 주변의 $\mathrm{pH}$ 가 수화젤의 $\mathrm{pK}_{\mathrm{a}}$ 보다 높아지면 네트워크가 팽윤 
되면서 탑재된 물질이 수화젤 내부로부터 급속하게 방출된 다. ${ }^{11-15}$ 이러한 $\mathrm{pH}$ 감응성 수화젤의 $\mathrm{pH}$ 에 따른 네트워크 구 조의 변화와 그에 따른 내부 탑재 물질의 선택적 방출 특성 을 화장품 기능성 물질의 피부전달에 응용할 수 있다. 예를 들어, 화장품을 사용하기 전에는 낮은 $\mathrm{pH}$ 에서 기능성 물질 이 탑재된 수화젤 입자를 보관하여 기능성 물질을 보호하고, 화장품을 피부에 바르면 피부의 $\mathrm{pH}$ 를 약 6 정도로 유지하려 는 인체의 항상성 때문에 주변의 $\mathrm{pH}$ 가 상승하게 되면서 탑 재된 기능성 물질이 방출되어 피부로의 흡수가 진행되는 지 능형 약물 전달시스템을 화장품 분야에서 구현할 수 있다. 또한 수화젤은 내부에 탑재된 물질, 특히 세포나 단백질과 같은 생체물질을 외부환경으로부터 보호하고 안정화시킬 수 있는 특징이 있으므로 ${ }^{16-18} \mathrm{pH}$ 감응성 수화젤 내부에 탑재된 화장품 기능성 물질의 활성을 장기간 유지하는데 도움을 줄 수 있다.

기능성 화장품에 사용되고 있는 알부민(albumin)은 생체세 포나 체액 중에 넓게 분포되어 있는 단순단백질로 글로불린 과 함께 세포의 기초물질을 구성하고, 동식물의 조직에 널리 존재하며, 피부에 적용 시, 주름을 개선하고 피부에 수분을 보유하는 등의 기능을 가지고 있는 것으로 알려져 있다. ${ }^{19-24}$ 그러나 알부민은 생체물질인 단백질이기 때문에 화장품 소재 로의 우수한 효능에도 불구하고 외부 환경요인에 민감하게 반응하여 변성에 의한 역가 하락과 열에 의한 취약성 등 화 장품 원료로서 사용할 때 불안정성이 문제가 되고 있다. 따 라서 이러한 알부민을 화장품 원료로 사용하기 위해서는 알 부민을 화장품 제형 내에서는 안정하게 보존하고, 피부에 도 포 시 빠른 방출로 피부에 흡수될 수 있는 전달시스템의 개 발이 필요하다.

따라서 본 연구에서는 $\mathrm{pH}$ 감응성 수화젤을 이용하여 외부 환경에 불안정한 활성물질을 화장품 제형 내에서는 안정하게 보존하고, 피부에 도포 시 빠른 방출로 피부에 흡수될 수 있 는 지능형 전달시스템을 구현하기 위하여, 분산광중합을 이 용하여 $\mathrm{pH}$ 감응성을 가지는 $\mathrm{P}(\mathrm{MAA}-\mathrm{co}-\mathrm{PEGMA})$ 수화젤 입 자를 합성하고 알부민을 탑재시킨 후, $\mathrm{P}(\mathrm{MAA}-c o-P E G M A)$ 수화젤이 $\mathrm{pH}$ 에 따른 선택적 방출, 피부투과율, 그리고 내부 에 탑재된 알부민의 안정성에 미치는 영향을 관찰하였다.

\section{실 험}

재료. 실험에 사용된 methacrylic acid(MAA, molecular weight 86), poly(ethylene glycol) methacrylate(PEGMA, molecular weight 360), poly(ethylene glycol) dimethacrylate (PEGDMA), 실리콘 오일, 알부민, 그리고 펩신은 SigmaAldrich사(미국)로부터, Irgacure ${ }^{\circledR} 184$ 는 Ciba사(미국)로부터 구입하여 사용하였다. Dimethicone copolyol(DC)은 (주)네비온 (한국)으로부터 제공받았으며, HPLC 분석을 위하여 HPLC grade water는 B\&사(미국)로부터, acetonitrile(ACN)은 Fisher 사(미국)로부터, 그리고 $99+\%$ trifluoroacetic $\operatorname{acid(TFA)ㄴㅡㄴ~}$ Sigma-Aldrich사(미국)로부터 구입하여 사용하였다.

$\mathrm{P}(\mathrm{MAA}-\mathrm{Co}-\mathrm{PEGMA})$ 수화젤 입자의 합성. 공중합 고분자 수화젤인 $\mathrm{P}(\mathrm{MAA}-\mathrm{co}-\mathrm{PEGMA})$ 입자를 합성하기 위한 단량체 의 조성은 $\mathrm{MAA}$ 와 $\mathrm{PEGMA}$ 중 $\mathrm{EG}$ 를 각각 $1: 1,0.8: 1$. 그리 고 $0.6: 1$ 몰비로 혼합한 후, 각각의 단량체 혼합물들에 대하 여 단량체 대비 가교제인 PEGDMA를 $0.75 \mathrm{~mol} \%$, Irgacure ${ }^{\circledR}$ 184 를 $0.5 \mathrm{wt} \%$, 그리고 전체 질량 대비 초순수를 $25 \mathrm{wt} \%$ 첨 가하였다. 이 혼합물들을 분산안정제인 $\mathrm{DC}$ 가 $10 \mathrm{wt} \%$ 함유 된 실리콘 오일 $30 \mathrm{~mL}$ 에 투입하고 산소를 제거하기 위하여 질소를 2분 동안 주입한 후, ultrasonic processor(VCX750, Sonics \& Materials)를 이용하여 1분 동안 수용상인 혼합물을 오일상에 분산시켰다. 분산이 완료된 후, 300 초 동안 $\mathrm{UV}$ 를 조사하여 입자형태의 수화젤을 중합하고, 합성된 수화젤 입 자는 여러 차례 초순수를 사용한 원심분리를 통하여 세척하 였다. 세척이 완료된 수화젤 입자는 동결건조장치(Ecospin $3180 \mathrm{c}$, Bio Tron)를 이용하여 건조한 후 다음 실험에 사용하 였다. Scheme 1에 P(MAA-co-PEGMA)의 합성방법을 나타 내었으며, 합성된 수화젤 입자의 형태와 크기는 SEM(Jeol 6300)을 사용하여 관찰하였다.

$\mathrm{P}(\mathrm{MAA}-\mathrm{Co}-\mathrm{PEGMA})$ 수화젤 입자의 팽윤. 외부 $\mathrm{pH}$ 에 따 른 $\mathrm{P}(\mathrm{MAA}-\mathrm{co}-\mathrm{PEGMA})$ 수화젤 입자의 팽윤거동을 관찰하기 위하여 건조한 수화젤 입자의 질량을 측정한 후, $\mathrm{pH} 2.0$ 에서 8.0 사이의 완충용액에서 수화젤을 팽윤시켰다. 24 시간이 지 난 후, 팽윤상태의 수화젤 입자를 꺼내 외부에 묻은 물기를 제거한 후, 질량을 측정하였다. 수화젤의 평형 질량팽윤비는 팽윤 전 건조 수화젤의 질량에 대한 팽윤 후 수화젤의 질량 의 비로 계산하였다.

알부민의 탑재 및 방출. 알부민의 탑재는 $2 \mathrm{mg} / \mathrm{mL}$ 의 알부 민 수용액에 건조된 $\mathrm{P}(\mathrm{MAA}-\mathrm{co}$-PEGMA) 수화젤 입자 $0.05 \mathrm{~g}$ 을 넣고 일정 시간이 경과하면, 입자를 수용액에서 꺼내 감 압 필터링 장치에서 증류수로 표면세척을 한 후 동결건조를 통하여 완료하였다. 알부민의 방출은 탑재가 완료된 건조 $\mathrm{P}(\mathrm{MAA}-\mathrm{co}-\mathrm{PEGMA})$ 수화젤 입자를 $\mathrm{pH}$ 4.0과 6.0 완충용액 에 각각 넣고 일정한 시간 간격으로 용액 내 알부민의 농도 를 $\mathrm{HPLC}$ 를 사용하여 측정하여 방출된 알부민의 양을 미리 준비한 보정곡선을 이용하여 계산하였다. 알부민의 분석에 사 용된 $\mathrm{HPLC}$ 는 Waters사의 600s controller, $616 \mathrm{pump}, 717$ plus autosampler, 그리고 996 photodiode array detector로 구 성되었다. 단일이동상으로 $80 \%$ 의 water와 $0.1 \%(\mathrm{v} / \mathrm{v})$ TFA가 포함된 $20 \% \mathrm{ACN}$ 을 사용하였으며, 유속은 $1.0 \mathrm{~mL} / \mathrm{min}$ 으로 수행하였다. 분석파장은 $290 \mathrm{~nm}$, 컬럼은 Agilent사의 TC$\mathrm{C} 18(4.6 \times 250 \mathrm{~mm}, 5 \mu \mathrm{m}$ particle size $)$ 을 사용하였다.

알부민의 피부투과. $\mathrm{pH}$ 에 따라 $\mathrm{P}(\mathrm{MAA}-c o-\mathrm{PEGMA})$ 수화 젤 입자로부터 방출된 알부민의 피부투과를 관찰하기 위하여 
<smiles>C=C(C)C(=O)O</smiles>

(a)<smiles>C=C(C)C(=O)OCCC(C)OCCC(C)(C)OC(=O)C(C)=C[CH+]C(C)(C)O</smiles>

(b)

(c)

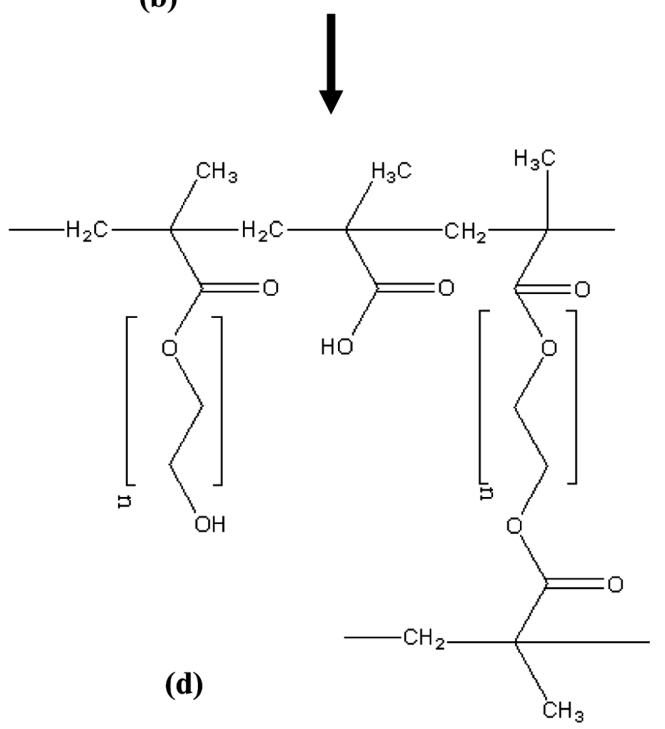

Scheme 1. Synthesis of P(MAA-co-PEGMA): (a) MAA; (b) PEGMA;

(c) PEGDMA; (d) P(MAA-co-PEGMA).

Franz diffusion cell(FCDV-15, Labfine)과 human epidermis (Hans Biomed)를 사용하여 피부투과 실험을 수행하였다. PBS 를 이용하여 세척한 human epidermis를 피부 표면이 위로 가 도록 해서 diffusion cell에 펴주면서 부착하고 윗부분에는 알 부민이 탑재된 $\mathrm{P}(\mathrm{MAA}-c o-\mathrm{PEGMA})$ 수화젤 입자 $2 \mathrm{mg}$ 을 도 포한 후, $\mathrm{pH}$ 4와 6의 완충용액 $1 \mathrm{~mL}$ 를 각각 넣어주었고, 아 랫부분에는 피부를 투과한 알부민을 수용할 수 있도록 역시 $\mathrm{pH}$ 4와 6의 완충용액으로 각각 채워주었다. 각각의 diffusion cell은 $36{ }^{\circ} \mathrm{C}$ 와 $500 \mathrm{rpm}$ 의 조건으로 24 시간 동안 유지한 후, 피부를 투과하여 아랫부분으로 이동한 알부민 농도를 HPLC 를 이용하여 분석하였다.

알부민의 안정성. $\mathrm{P}(\mathrm{MAA}-c o-\mathrm{PEGMA})$ 수화젤이 알부민의 안정성에 미치는 영향을 조사하기 위하여, 알부민 수용액과 알부민을 탑재한 P(MAA-co-PEGMA) 수화젤 입자가 포함된 수용액 각각에 단백질 분해효소인 펩신을 $1.0 \mathrm{wt} \%$ 용해하고 $36^{\circ} \mathrm{C}$ 에서 자석교반기를 이용하여 지속적으로 교반을 하였다. 모든 용액의 $\mathrm{pH}$ 조건은 펩신의 활성이 최적이 되도록 2.0 을 유지하였고, 24 시간 후 알부민의 변성 여부를 HPLC를 이용 하여 분석하였다. 수화젤 입자에 탑재시킨 알부민의 경우는 펩신 처리 후, $\mathrm{pH} 6.0$ 의 완충용액에 펩신으로 처리한 알부민 이 탑재된 수화젤 입자를 옮겨서 수화젤 내부에 탑재된 알부 민을 방출시켜서 알부민의 변성 여부를 HPLC를 이용하여 분 석하였다.

\section{결과 및 토론}

$\mathrm{P}$ (MAA-co-PEGMA) 수화젤 입자의 합성과 팽윤거동. Figure 1은 본 연구에서 분산광중합으로 합성한 $\mathrm{P}(\mathrm{MAA}-\mathrm{co}-$ PEGMA) 수화젤 입자를 SEM을 사용하여 관찰한 사진이다. 그림에서 볼 수 있는 바와 같이 입자는 모두 균일한 구형의 모양을 하고 있었으며, 평균크기는 약 $2 \mu \mathrm{m}$ 이었다. P(MAAco-PEGMA) 수화젤 입자의 $\mathrm{pH}$ 감응성을 조사하기 위하여 수 화젤 입자를 $\mathrm{pH} 2.0$ 에서 8.0 사이의 완충용액에 투입하고 24 시간이 경과한 후, $\mathrm{pH}$ 에 따른 입자의 평형 질량팽윤비를 측 정하였다. Figure 2는 P(MAA-co-PEGMA) 수화젤 입자의 $\mathrm{pH}$ 에 따른 평형 질량팽윤비를 보여준다. 수화젤을 구성하는 $\mathrm{MAA}$ 와 $\mathrm{EG}$ 의 조성비에 관계없이 모든 조성의 수화젤 입자 들이 $\mathrm{pH} 5$ 를 전후하여 급격한 팽윤비의 변화를 보여주었다. 이것은 $\mathrm{P}(\mathrm{MAA}-\mathrm{co}-\mathrm{PEGMA})$ 수화젤의 $\mathrm{pK}_{\mathrm{a}}$ 에 해당되는 $\mathrm{pH} 5$ 보다 높은 $\mathrm{pH}$ 에서는 수화젤의 $\mathrm{MAA}$ 에 존재하는 카르복시기 가 이온화되어 음전하를 띠게 되고 이 음전하들 사이에 정전 기적 반발력이 발생하여 수화젤 네트워크가 급격하게 팽창하 기 때문이다. 그리고 $\mathrm{P}(\mathrm{MAA}-\mathrm{co}-\mathrm{PEGMA})$ 수화젤의 MAA와 $\mathrm{EG}$ 의 조성 중 $\mathrm{MAA}$ 의 비율이 감소함에 따라서 평형 질량팽 윤비가 $\mathrm{pH}$ 5보다 높은 $\mathrm{pH}$ 에서 감소함을 확인하였다. 이것은 수화젤을 구성하는 $\mathrm{MAA}$ 의 비율이 감소함에 따라서 $\mathrm{pK}_{\mathrm{a}}$ 보 다 높은 $\mathrm{pH}$ 에서 이온화되는 카르복시기가 감소하게 되고 결 
과적으로 수화젤 네트워크 내부에 형성되는 정전기적 반발력 이 감소하기 때문이다. 본 연구에서는 낮은 $\mathrm{pH}$ 와 높은 $\mathrm{pH}$ 에 서의 질량팽윤비의 차이가 가장 큰 수화젤이 $\mathrm{pH}$ 에 따른 수 화젤 입자로부터 알부민 방출량의 차이가 가장 클 것으로 예 상되어, $\mathrm{MAA}$ 와 $\mathrm{EG}$ 가 $1: 1$ 의 조성을 가지고 있는 $\mathrm{P}(\mathrm{MAA}-$

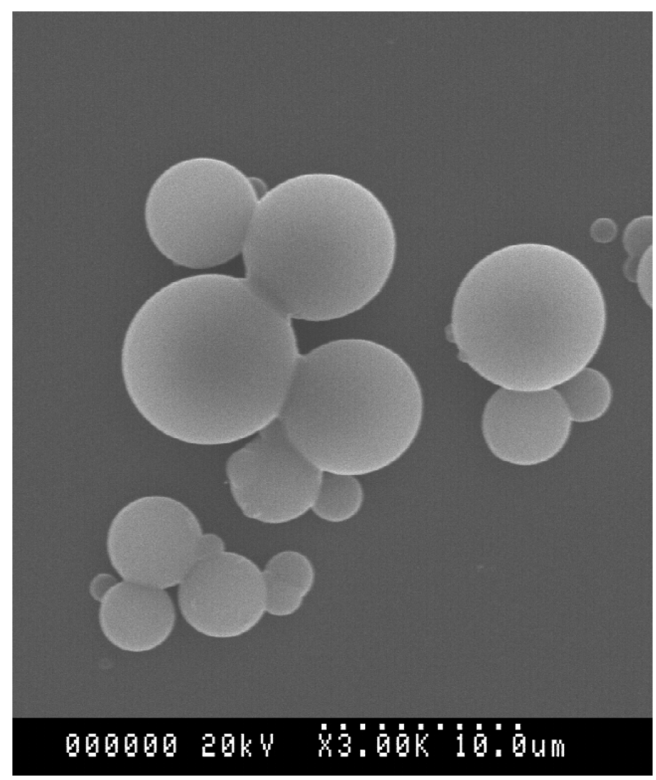

Figure 1. SEM image of P(MAA-co-PEGMA) hydrogel particles. Scale bar is $10 \mu \mathrm{m}$.

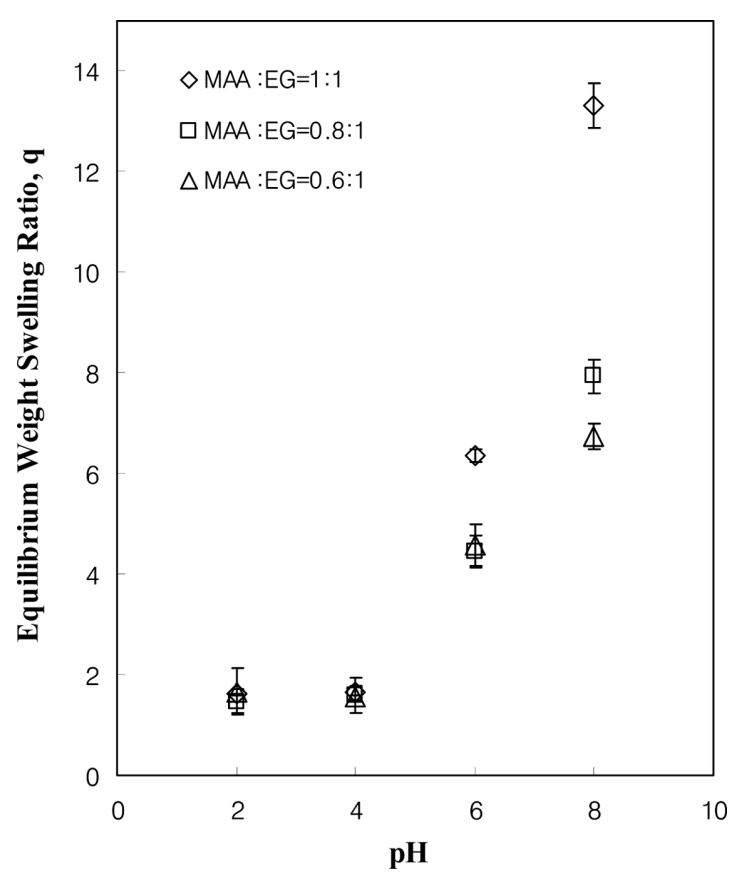

Figure 2. Equilibrium weight swelling ratio of P(MAA-co-PEGMA) hydrogel particles having various MAA and EG compositions; MAA:EG $=1: 1(\diamond), 0.8: 1(\square)$, and 0.6:1 $\triangle)($ average $\pm \mathrm{SD}, \mathrm{n}=3)$.
co-PEGMA) 수화젤 입자를 사용하여 이후의 실험을 진행하 였다.

알부민이 탑재된 $\mathrm{P}(\mathrm{MAA}-\mathrm{Co}-\mathrm{PEGMA})$ 수화젤 입자로부 터 $\mathrm{pH}$ 에 따른 알부민의 방출거동. $\mathrm{MAA}$ 와 $\mathrm{EG}$ 가 $1: 1$ 의 조 성을 가지고 있는 $\mathrm{P}(\mathrm{MAA}-c o-\mathrm{PEGMA})$ 수화젤 입자를 고농 도 $(2 \mathrm{mg} / \mathrm{mL})$ 의 알부민 수용액에 넣은 후, 3 시간이 경과한 후 그 탑재량을 조사한 결과, 수화젤 $\mathrm{g}$ 당 평균 99.2( \pm 8.9$) \mathrm{mg}$ 의 알부민이 탑재되었다. 이와 같이 알부민이 탑재된 P(MAAco-PEGMA) 수화젤 입자로부터 $\mathrm{pH}$ 에 따라 방출되는 알부민 의 거동을 Figure 3 에 나타내었다. 그림에서와 같이 주변의 $\mathrm{pH}$ 에 따라서 P(MAA-co-PEGMA) 수화젤 입자로부터 방출 되는 알부민의 방출량에 큰 차이를 보여주었는데, $\mathrm{pH} 4.0$ 에 서는 매우 소량의 알부민이, 반면에 $\mathrm{pH}$ 6.0에서는 초기부터 다량의 알부민이 방출되는 것을 관찰할 수 있었다. 방출실험 시작 후 300 분이 경과하였을 때 $\mathrm{pH} 4.0$ 과 6.0 에서 각각 10.1 과 $53.7 \mathrm{mg} / \mathrm{g}$ 의 알부민이 수화젤 입자로부터 방출되었다. $\mathrm{P}(\mathrm{MAA}-\mathrm{co}-\mathrm{PEGMA})$ 수화젤 입자의 $\mathrm{pH}$ 에 따른 방출거동은 $\mathrm{pH}$ 에 따른 수화젤 네트워트 구조의 팽윤 차이에 의한 것으 로 설명할 수 있다. 앞서 언급한 팽윤실험의 결과에서 볼 수 있듯이 $\mathrm{pH} 4.0$ 에서는 $\mathrm{MAA}$ 의 카르복시기들이 이온화되지 않 으므로 카르복시기들 사이에 수소결합이 유지되어 수화젤이 팽윤하지 않아서 내부에 탑재된 알부민이 수화젤 입자로부터 거의 방출되지 못했지만, $\mathrm{pH}$ 6.0에서는 $\mathrm{MAA}$ 의 카르복시기 들이 이온화되면서 정전기적 반발력이 발생하여 수화젤의 네

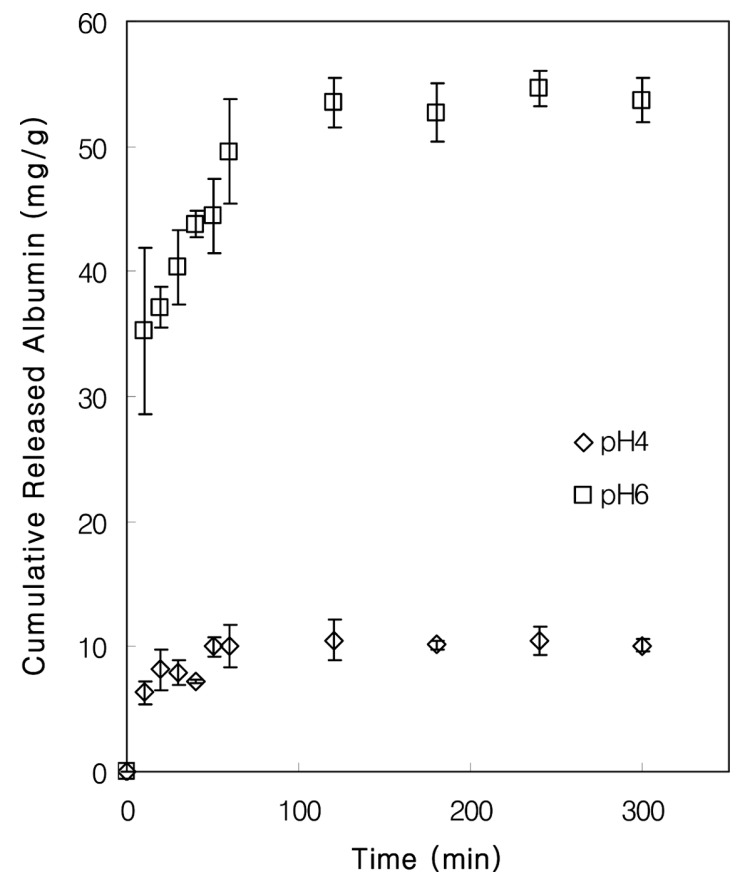

Figure 3. Cumulative amount of albumin released from $\mathrm{P}(\mathrm{MAA}-\mathrm{co}$ PEGMA) hydrogel particles(MAA:EG=1:1) as a function of time in $\mathrm{pH} 4.0(\diamond)$ and $6.0(\square)$ buffer solutions (average $\pm \mathrm{SD}, \mathrm{n}=3$ ). 
트워크 구조가 크게 팽창되면서 탑재된 알부민이 빠르게 방 출된 것이다. 이러한 결과는 본 연구에서 목적으로 하는 $\mathrm{pH}$ 의 변화에 따라서 선택적으로 알부민을 방출할 수 있는 전달 체로서 P(MAA-co-PEGMA) 수화젤이 사용 가능함을 보여준다.

알부민이 탑재된 $\mathrm{P}(\mathrm{MAA}-\mathrm{Co}-\mathrm{PEGMA})$ 수화젤 입자로부 터 $\mathrm{pH}$ 에 따른 알부민의 피부투과 거동. 이상에서 살펴본 $\mathrm{P}(\mathrm{MAA}-\mathrm{co}$-PEGMA) 수화젤의 $\mathrm{pH}$ 에 따른 방출거동이 실제 피부에 대한 알부민의 투과거동에 미치는 영향을 살펴보기 위하여, 인체 피부를 이용하여 $\mathrm{pH}$ 변화에 따라 수화젤 입자 로부터 방출된 알부민이 피부에 투과되는 거동을 관찰하였으 며, 그 결과를 Figure 4에 나타내었다. 알부민의 피부투과율 은 $\mathrm{pH}$ 6에서 알부민이 탑재된 P(MAA-co-PEGMA) 수화젤 입자로부터 방출될 수 있는 최대 알부민 농도에 대하여 $\mathrm{pH}$ 4와 6에서 수화젤 입자로부터 각각 방출된 알부민의 양을 HPLC로 분석하여 계산하였다. Figure 4에서 볼 수 있는 바 와 같이, $\mathrm{pH}$ 4에서는 알부민의 피부투과가 거의 일어나지 않 은 반면, $\mathrm{pH}$ 6에서는 상대적으로 높은 피부투과율을 나타내 었다. 그 이유는, 앞서 $\mathrm{pH}$ 에 따른 방출실험 결과에서 보여준 $\mathrm{P}(\mathrm{MAA}-\mathrm{co}-\mathrm{PEGMA})$ 수화젤 입자의 $\mathrm{pH}$ 에 따른 선택적 방출 거동 때문이라고 설명할 수 있는데, $\mathrm{pH}$ 6에서는 $\mathrm{pH}$ 4에 비 하여 다량의 알부민이 수화젤 입자로부터 방출되기 때문에 그만큼 다량의 알부민이 피부에 흡수될 수 있다. 이와 같은 결과는, 본 연구에서 목적으로 하는 알부민이 탑재된 P(MAAco-PEGMA) 수화젤 입자가 피부에 도포되고 주위에 $\mathrm{pH}$ 가 상

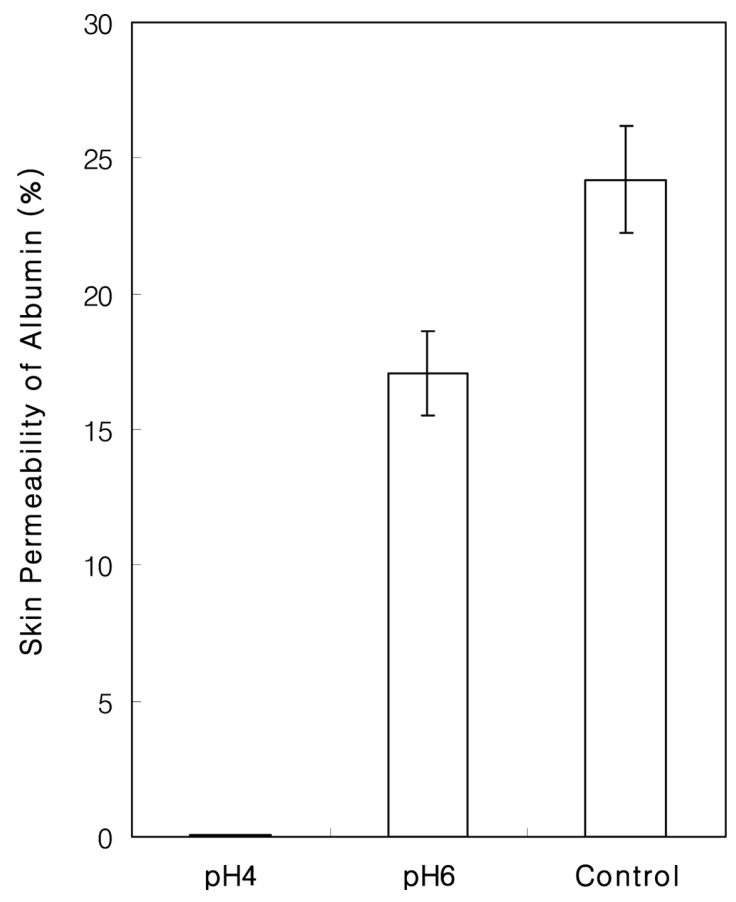

Figure 4. Skin permeability of the albumin released from the albumin-loaded P(MAA-co-PEGMA) hydrogel particles (MAA:EG=1:1) at $\mathrm{pH} 4.0$ and 6.0 (average $\pm \mathrm{SD}, \mathrm{n}=3$ ).
승하면 수화젤 입자에 탑재된 알부민이 방출되어 피부에 흡 수되는 지능형 전달시스템의 구현이 가능함을 보여준다. 한 편, $\mathrm{pH}$ 6에서 수화젤 입자로부터 방출된 알부민의 피부투과 율은 동일한 농도에서 수화젤에 탑재하지 않은 알부민 수용 액(control)의 약 $71 \%$ 인 것을 볼 수 있었다. 이와 같이 수화 젤에 탑재된 알부민의 피부투과율이 수화젤에 탑재하지 않은 알부민의 피부투과율보다 작은 이유는, 알부민이 수화젤 입 자로부터 방출된 후 피부에 흡수될 때, 피부 위에 도포된 수 화젤 입자가 알부민이 피부까지 도달하는데 장벽 역할을 했 기 때문으로 추측할 수 있다. 그럼에도 불구하고 피부투과율 의 차이는 크지 않았으며, 본 피부투과 실험에서 사용된 diffusion cell 내에서 피부면적은 실제 화장품 적용에서 도포 되는 피부면적에 비해서는 상당히 작으므로 실제 사용에서는 수화젤 입자에 의한 장벽효과는 거의 없을 것으로 예상할 수 있다.

$\mathrm{P}$ (MAA-Co-PEGMA) 수화젤이 탑재된 알부민의 안정성에 미치는 영향. $\mathrm{P}(\mathrm{MAA}-\mathrm{co}$-PEGMA) 수화젤이 내부에 탑재된 알부민의 안정성에 미치는 영향을 조사하기 위하여 펩신을 이용한 실험을 진행하였다. 펩신은 대표적인 단백질 분해 효 소로 페닐알라닌(phenylalanine)과 타이로신(tyrosine)과 같은 방항족 아미노산이 있는 부분을 잘라내며, $\mathrm{pH}$ 가 낮은 산성환 경에서 최적의 활성을 나타낸다. 따라서 수화젤 입자에 탑재 가 되지 않은 알부민은 펩신에 의하여 분해가 될 것이며, 수 화젤 입자에 탑재된 알부민은 수화젤의 보호에 의하여 활성 이 유지될 것으로 예상할 수 있다. 알부민을 탑재한 P(MAAco-PEGMA) 수화젤 입자 수용액과 수화젤에 탑재하지 않은 알부민 수용액을 24시간 동안 펩신으로 처리한 후, HPLC를 이용한 분석결과를 Figure 5에 나타내었다. Figure 5(a)는 펩 신으로 처리하지 않은 순수한 알부민 수용액의 HPLC 결과 로, 변성이 일어나지 않은 알부민의 경우, 22.5 분 부근에서 특성 피크가 존재하는 것을 알 수 있었다. Figure 5(b)는 펩 신으로 처리한 알부민 수용액의 HPLC 결과로, 22.5분에 특 성 피크가 존재하지 않은 것을 볼 수 있다. 이것은 펩신에 의 하여 알부민이 분해된 결과이다. 그러나 알부민을 P(MAAco-PEGMA) 수화젤 입자에 탑재하고 펩신으로 처리한 경우 에는, Figure 5(c)에서 볼 수 있듯이 펩신 처리 후에도 변성 되지 않은 알부민이 다량 존재하는 것을 볼 수 있었다. $\mathrm{P}(\mathrm{MAA}-c o-\mathrm{PEGMA})$ 수화젤의 알부민에 대한 안정성을 정량 화하기 위하여 HPLC 결과에 나타난 모든 피크에 대한 22.5 분의 알부민 특성 피크의 비율을 Table 1에 계산하여 정리하 였다. 수화젤에 탑재하지 않은 알부민의 경우, 모든 알부민이 분해되었으나, 수화젤에 탑재된 알부민의 경우, 약 $20 \%$ 정도 만이 변성된 것으로 나타났다. 이러한 결과는 $\mathrm{P}(\mathrm{MAA}-\mathrm{co}-$ PEGMA) 수화젤이 예상한 바대로, 내부에 탑재된 알부민을 외부 환경으로부터 보호하여 안정성을 유지하는데 기여하는 것을 말해준다. 

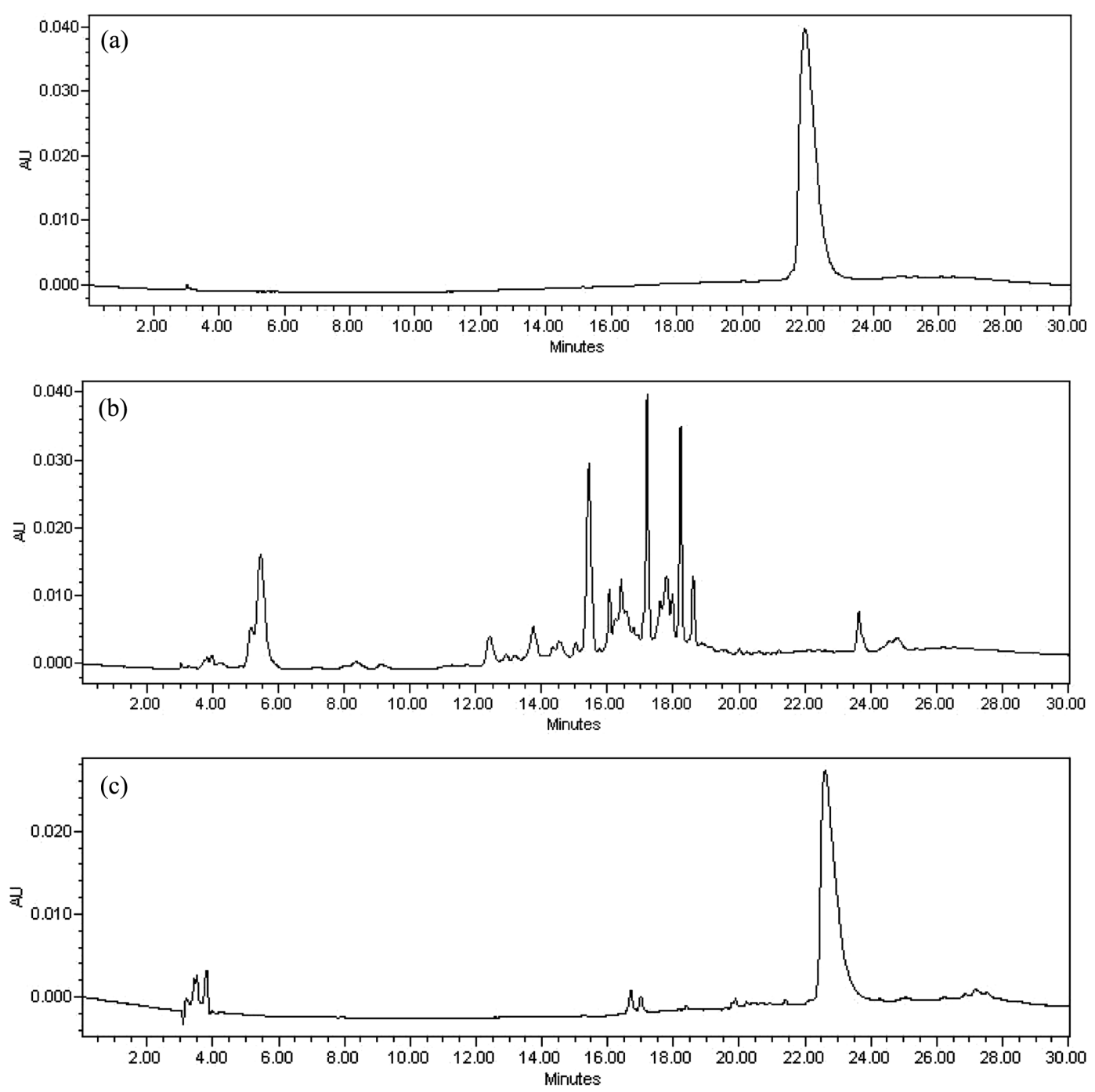

Figure 5. HPLC chromatograms of (a) pure albumin solution with no pepsin; (b) albumin solution treated with pepsin; (c) albumin that was incorporated within P(MAA-co-PEGMA) hydrogel particles and then treated with pepsin.

Table 1. Ratio of the Peak Area of the Native Albumin to the Area of All Peaks on the HPLC Chromatograms in Figure 5

\begin{tabular}{|c|c|}
\hline Sample & $\begin{array}{c}\% \text { area of peak at } \\
22.5 \mathrm{~min}\end{array}$ \\
\hline $\begin{array}{l}\text { The pure albumin, which was not loaded } \\
\text { into the hydrogels, dissolved in pH } 2.0 \\
\text { buffer solution with no pepsin (Figure } 5(\mathrm{a}) \text { ) }\end{array}$ & $95.2( \pm 1.2)$ \\
\hline $\begin{array}{l}\text { The albumin, which was not loaded into the } \\
\text { hydrogels, placed in pepsin solution at } \mathrm{pH} \\
2.0 \text { (Figure } 5(\mathrm{~b}) \text { ) }\end{array}$ & 0 \\
\hline $\begin{array}{l}\text { The albumin, which was incorporated within } \\
\text { hydrogels and placed in pepsin solution at } \\
\text { pH } 2.0 \text {, then released at pH } 6.0 \text { buffer solu- } \\
\text { tion (Figure } 5(\mathrm{c}) \text { ) }\end{array}$ & $76.2( \pm 1.0)$ \\
\hline
\end{tabular}

\section{결 론}

본 연구에서는 분산광중합을 이용하여 $\mathrm{pH}$ 감응성 수화젤 인 P(MAA-co-PEGMA) 수화젤을 평균 크기 약 $2 \mu \mathrm{m}$ 의 구 형 입자로 합성하였다. 합성된 $\mathrm{P}(\mathrm{MAA}-\mathrm{co}-\mathrm{PEGMA})$ 수화젤 입자는 수화젤의 MAA에 존재하는 카르복시기의 이온화에 의하여 $\mathrm{pH} 5$ 를 전후로 한 급격한 팽윤비의 변화를 보여주었 고, 이러한 $\mathrm{pH}$ 에 따른 팽윤거동은 수화젤 내부에 탑재된 알 부민의 $\mathrm{pH}$ 에 따른 선택적 방출거동을 가져왔다. 실제 인체 피부를 이용한 피부투과 실험 결과, $\mathrm{pH}$ 4에서는 알부민의 피 부투과가 거의 일어나지 않은 반면, $\mathrm{pH}$ 6에서는 상대적으로 높은 피부투과율을 나타내었다. 그리고 P(MAA-co-PEGMA) 수화젤은 내부에 탑재된 알부민을 외부 환경으로부터 보호하 여 알부민의 활성을 유지시킬 수 있음을 확인하였다. 이러한 
결과들은 $\mathrm{P}(\mathrm{MAA}-\mathrm{co}-\mathrm{PEGMA})$ 수화젤 입자가 본 연구에서 개발하고자 하는 $\mathrm{pH}$ 감응성 수화젤을 이용하여 $\mathrm{pH}$ 변화에 따라 화장품 기능성 물질을 선택적으로 방출하고 동시에 내 부에 탑재된 물질의 안정성을 유지할 수 있는 지능형 전달시 스템에 적용 가능함을 보여준다.

감사의 글: 본 연구는 2012학년도 홍익대학교 학술연구진 흥비에 의하여 지원되었으며, 이에 감사드립니다.

\section{참 고 문 헌}

1. N. A. Peppas, P. Bures, W. Leobandung, and H. Ichikawa, Eur. J. Pharm. Biopharm., 50, 27 (2000).

2. B. G. Chung, K. H. Lee, A. Khademhosseini, and S. H. Lee, Lab Chip, 12, 45 (2012).

3. C. Gonzalez-Chomon, A. Concheiro, and C. Alvarez-Lorenzo, Materials, 4, 1927 (2011).

4. J. Cabral and S. C. Moratti, Future Med. Chem., 3, 1877 (2011).

5. E. Jabbari, Curr. Opin. Biotechnol., 22, 655 (2011).

6. B. Jeong, S. W. Kim, and Y. H. Bae, Adv. Drug Deliv. Rev., 54, 37 (2002).

7. I. Tomatsu, K. Peng, and A. Kros, Adv. Drug Deliv. Rev., 63, 1257 (2011).

8. Z. Li and J. Guan, Expert Opin. Drug Deliv., 8, 991 (2011).

9. L. Zha, B. Banik, and F. Alexis, Soft Matter, 7, 5908 (2011).

10. A. K. Bajpai, J. Bajpai, R. Saini, and R. Gupta, Polym. Rev., 51, 53 (2011).
11. A. C. Foss, T. Goto, M. Morishita, and N. A. Peppas, Eur. J. Pharm. Biopharm., 57, 163 (2004).

12. G. Mocanu, D. Mihai, V. Dulong, L. Picton, and D. Le Cerf, Carbohydr. Polym., 87, 1440 (2012).

13. B. Kim, S. H. Kim, and W. Ryoo, J. Biomater. Sci.-Polym. Ed., 20, 427 (2009).

14. E. Lee and B. Kim, Polym. Bull., 67, 67 (2011).

15. K. M. Wood, G. M. Stone, and N. A. Peppas, Acta Biomater., 6, 48 (2010).

16. S. Zhang, Nat. Mater., 3, 7 (2004).

17. A. Revzin, R. J. Russell, V. K. Yadavalli, W. G. Koh, C. Deister, D. D. Hile, M. B. Melott, and M. V. Pishko, Langmuir, 17, 5440 (2001).

18. J. Zhu and R. E. Marchant, Expert Rev. Med. Devices, 8, 607 (2011).

19. A. M. Kligman and C. M. Papa, J. Soc. Cosmetic Chemists, 16, 557 (1965).

20. T. Peters, All about Albumin: Biochemistry, Genetics, and Medical Applications, Academic Press, New York, 1996.

21. R. Jiang, C. G. J. Hayden, R. J. Prankerd, M. S. Roberts, and H. A. E. Benson, J. Chromatogr. B, 682, 137 (1996).

22. S. Hasse, S. Kothari, H. Rokos, S. Kauser, N.Y. Schurer, and K. U. Schallreuter, Exp. Dermatol., 14, 182 (2005).

23. A. Kerr and J. Ferguson, Photodermatol. Photoimmunol. Photomed., 26, 56 (2010).

24. V. Sharma, A. Jaishankar, Y. C. Wang, and G. H. McKinley, Soft Matter, 7, 5150 (2011). 